\title{
Re-thinking Higher Education Curricula in the Era of Knowledge Economy: A Case Study of Course Codes in the National Curriculum of Pakistan
}

\author{
* Itbar Khan, Assistant Professor \\ ** Iftikhar Ahmad, Professor/Vice Chancellor \\ *** Rashid Ahmad, Professor/Dean
}

\begin{abstract}
The study reviewed the course codes at undergraduate level in selected universities and Higher Education Commission (HEC). The objectives of the study were to investigate the coding system of courses and propose a system for coding the courses at tertiary level in Pakistan. The coding system of different universities, inside and outside Pakistan, was analysed and a system of coding was proposed. The study found discrepancies in the coding of courses that cause difficulties for academic bodies and transfer of credits from one university to another. It is recommended that courses of a degree required may be divided in 1) General Education requirements, 2) Subject specific foundation courses, 3) subject specific major compulsory courses, and 4) subject specific major elective courses. For codes 2, 3 or 4 capital letters for a subject along with three numbers (xxx) may be used to specify each course of the university. The left digit of the three may be used for the hardship level. The courses 1xx, 2xx, 3xx and 4xx will be taught in the first, second, third and fourth year, respectively and research may be given 500 at undergraduate level, courses of 5 year may be placed in 5xx and research may be coded as 599. The graduate level courses for MPhil /MS /PhD may be coded as 6xx, $7 x x$ and $8 x x$ for MPhil and PhD all over the country.
\end{abstract}

Keywords: Higher education; Curriculum; courses, Codes; Pakistan

\section{Introduction}

Higher education witnessed great expansion after World War II because new technologies emerged which demand for more talented skilful human resources and knowledge based economy (Kromydas, 2017). Globalization and the revolution in technological communications are major forces of change in higher education (Moorey, 2004). In this knowledge based economies era of $21^{\text {st }}$ century, countries contributing more to knowledge are leading the world in economies (Brinkley, 2008).Good quality, merit-oriented, equitable and efficient higher education is the most crucial instrument for establishing knowledge based economy. Besides, higher education contributes to the attainment of social bonds, civic responsibility and tolerant society (Ministry of Education, 2009-10). The draft policy of Education, Pakistan 2017 while emphasizing on the role of higher education states that the "Catalytic role of higher education is not limited to nurturing potentials of individual students for their career; it provides highly skilled human resources needed for economic development, social transformation, and political enlightenment of whole society". Sustainable Development Goals (SDGs) also give due importance to education for development and that is the reason that the fourth goal is related to quality education for all (United Nations, 2017). However, quality and process oriented education is the demand of the time as according to William (2007) procedural knowledge is the demand of university students and there is little evidence that universities are meeting this challenge because they did not go side by side with the change in knowledge economy.

It is evident that quality higher education is more than essential for knowledge economy and the forerunners in the creation and dissemination of knowledge are universities and colleges, and hence this new concept of knowledge economies has forced nations all across the globe for quality higher education. Unlike technological revolution era, in this new era developing and even underdeveloped nations can play key role like developed nations if they manage their higher education intelligently and up to the needs of the global demands. The notion of 'strong higher

\footnotetext{
* Department of Education, University of Malakand Email: educationmkd@ gmail.com

** Professor, Department of Physics, University of Malakand/Vice Chancellor, Gomal University, D.I. Khan

*** Professor/Dean Faculty of Education, University of Malakand
} 
education builds strong nations and economies' has intensely forced developing and underdeveloped nations to spend more on their higher education systems.

Pakistan also realized the importance of higher education and reformed the higher education system of the country by establishing a higher education commission (HEC) in 2002 in place of University Grants Commission (UGC). HEC was created to serve as an apex body for all matters related to policy, plans, programs, standards, funding and oversight of higher education in the country and transform the higher education sector to serve as an engine of growth for the socio-economic development in the country. HEC is responsible to formulate policies, guiding principles and priorities for higher education institutions for promoting socioeconomic development of the country (Ministry of Education, 2009-10). The Government of Pakistan with the support of all provinces evolved a vision for socio-economic development of the country. This Vision is based on six Pillars, and first Pillar is 'Putting People First: Developing Human and Social Capital'. Recognizing the role of higher education in socio-economic development around the globe, Pakistan Vision 2025 envisages to significantly increasing investment in human resources at the higher education level. It aims to:

"To achieve the objective of developing a knowledge economy, we target a sizeable increase in expenditure on higher education, currently from $0.2 \%$ of GDP to $1.4 \%$ of GDP, and significant expansion in higher education enrolment from currently 1.5 million to 5 million"

(Planning Commission, 2016).

In order to synchronize Pakistani degrees with the world and achieve best possible results in the form of quality graduates like Harvard, MIT, Stanford, Caltech etc., the United States Higher education model was adopted. According to this reformation, Pakistan shifted its higher education from 02-year bachelor and 02-year master degree as per National Education Policy 1978 to 04-year integrated BS degree program. Moreover, different required graduate tests like GRE General and GRE Subject are also introduced in Pakistan in the form of NTS General and NTS Subject for graduate admissions and other purposes.

The reformed higher education system has successfully achieved the first target of degree synchronization across the globe but the second target of quality higher education at par the US higher education has not been achieved. The main hurdle in the quality of higher education in Pakistan is the lack of understanding the reformed system and not acknowledging the source of the system (USA). Interestingly, the government has recognized the cause of the problem and has recently developed a new concept of 'knowledge corridor', where Pakistani students will be sent to USA on scholarship for higher education. The long-term success of this idea may not be underestimated but it is time and money consuming process. In this article, it has been discussed that the best, easier and cheaper approach to achieve quality higher education at par with US standards is to understand the reformed higher education system and once it is understood then it can be effectively implemented and desired possible results can be achieved. As the universities and colleges implement the policies framed by HEC, therefore a simple example of course codes of the few selected subjects from the curricula of HEC and universities are explored to check consistency of the policies within HEC, within universities and between HEC and universities.

\section{Methodology of the Study}

The primary method of research was document analysis. The researchers studied the framework provided by HEC for the development of curricula for social sciences and natural sciences. After that the developed curricula for the mentioned disciplines were thoroughly studied with special attention to the codes. The codes given to courses by different public and private universities were also studied and compared. The discrepancies were pointed out and a system of codes development was recommended.

\section{Results and Discussion}

Curriculum is the basic skeleton of education. A strong curriculum in higher education and its implementation as per the requirements and needs ensures quality higher education. In this study the curricula developed by the Higher Education Commission (HEC) of Pakistan, which are supposed to be implemented by all the institutions of higher learning including universities and colleges are thoroughly investigated. Moreover, the implementation of the framework for curricula in the universities is also examined. After going through the curricula, it has been observed that the roadmap provided by the HEC in Table 1, for the development of curriculum has not been followed by the curriculum developer. The possible reason for this problem is poor planning for the development of 
curriculum and including faculty members from all across the country for political correctness than appropriate persons with specialized skills and devotion. Moreover, the time provided, i.e., two meetings each of two days are not enough for the development of a curriculum of a subject.

Table 1

HEC Framework for Basic Sciences and Social Sciences

\begin{tabular}{llll}
\hline S\# & Categories & Courses & Credit Hours \\
\hline 1 & Compulsory Requirement (No Choice) & $9-9$ & $25-25$ \\
2 & $\begin{array}{l}\text { General Courses to be chosen from other } \\
\text { departments }\end{array}$ & $2-8$ & $21-24$ \\
& Discipline Specific Foundation Courses & $9-10$ & $30-33$ \\
4 & Major Courses including research project / & $11-13$ & $36-42$ \\
& Internship & & $12-12$ \\
5 & Electives within the major & $4-4$ & $124-136$ \\
Total & & $40-44$ & \\
\hline
\end{tabular}

Note: HEC, Framework for Basic Sciences and Social Sciences

Table 1 shows the course requirements of a major degree in a subject at undergraduate level. These requirements as per US higher education system can be divided into general education and core courses in the major subject. Where the general education requirements as per the table are compulsory courses and general courses from other departments. However the core courses are divided into discipline specific foundation courses, major courses including research project/ internship and elective courses. Although, there are many issues and problems with the present curricula of HEC and universities and hence extensive studies are required for bringing them up to level of the US education standards. However, in this study we have focused on the most fundamental aspect of curricula, i.e., course codes.

Course codes are generally combination of numbers with logical sequence when combined with defined letters for subjects simplifies the level of hardship without knowing their details. Hence, appropriate course codes is a basic tool for the management of the modern complex universities system. As these codes are supposed to be implemented by the universities, hence their detailed analysis and comparison with each other with universities and within each university is the most fundamental parameter that runs the whole system.

Table 2

Comparison of compulsory courses coding among Social Sciences Curricula of HEC

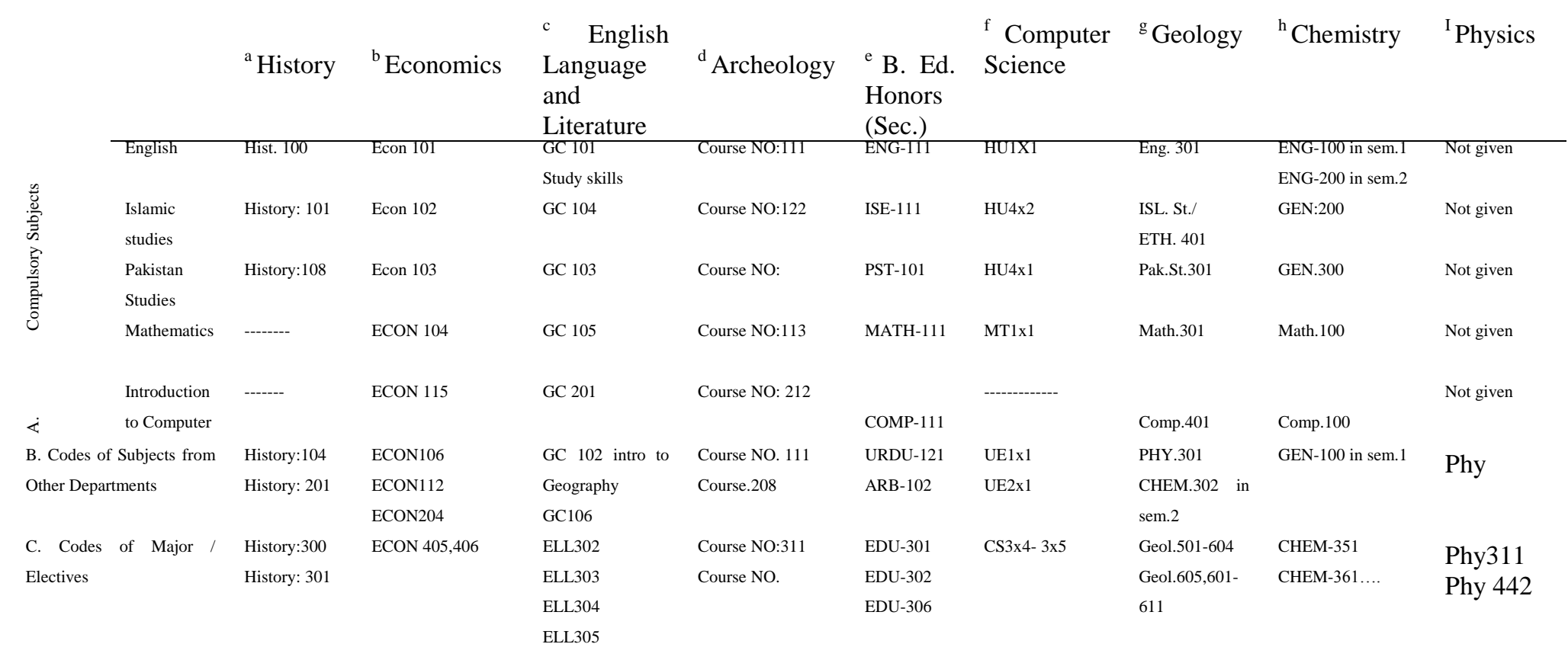

Note: ${ }^{2}$ Higher Education Commission (2017) Curriculum of History, Islamabad, Pakistan, ${ }^{\mathrm{b}}$ Higher Education Commission (2013) Curriculum of Economics BS, Islamabad, Pakistan, ${ }^{\mathrm{c}}$ Higher Education Commission (2017) Curriculum of English language and Literature, Islamabad, Pakistan, 
${ }^{\mathrm{d}}$ Higher Education Commission (2015) Curriculum of Archaeology, Islamabad, Pakistan, ${ }^{\mathrm{e}}$ Higher Education Commission (2012) B.Ed. honor, 04 year, Islamabad, Pakistan, ${ }^{\mathrm{f}}$ Higher Education Commission (2013) Curriculum of Physics BS/MS, Islamabad, Pakistan, ${ }^{g}$ Higher Education

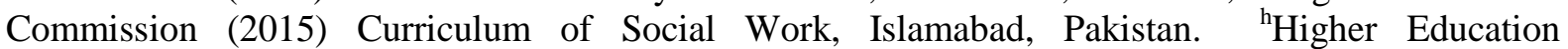
Commission (2013) Curriculum of Tourism and Hotel Management, Islamabad, Pakistan. ${ }^{\mathrm{i}}$ Higher Education Commission (2013) Curriculum of Chemistry, Islamabad, Pakistan ${ }^{\mathrm{j}}$ Higher Education Commission (2015) Curriculum of Islamic Studies, Islamabad, Pakistan

The course codes from HEC curricula for history, English ... Physics are compared in Table 2. The comparison is provided for three categories, i.e., compulsory courses, courses from other disciplines and major courses. Although, there are two to four compulsory courses of English and mathematics but one of each is represented to avoid repetition and the same has also done with the major courses. It is clear from the table that no logical sequence has been followed in the course codes. It does not seem that the curricula have been developed under the aegis of one central body. Some disciplines have started codes from 300, others have used the alphabetical part of the code of the discipline even for compulsory subjects.

The researcher took the coding system of one old university, Peshawar University, established in 1950 and one comparatively new university, University of Malakand, established in 2001 in order to know if there is any uniformity in coding system within the universities and between the 2 universities.

Table 3

Course Codes at the University of Peshawar

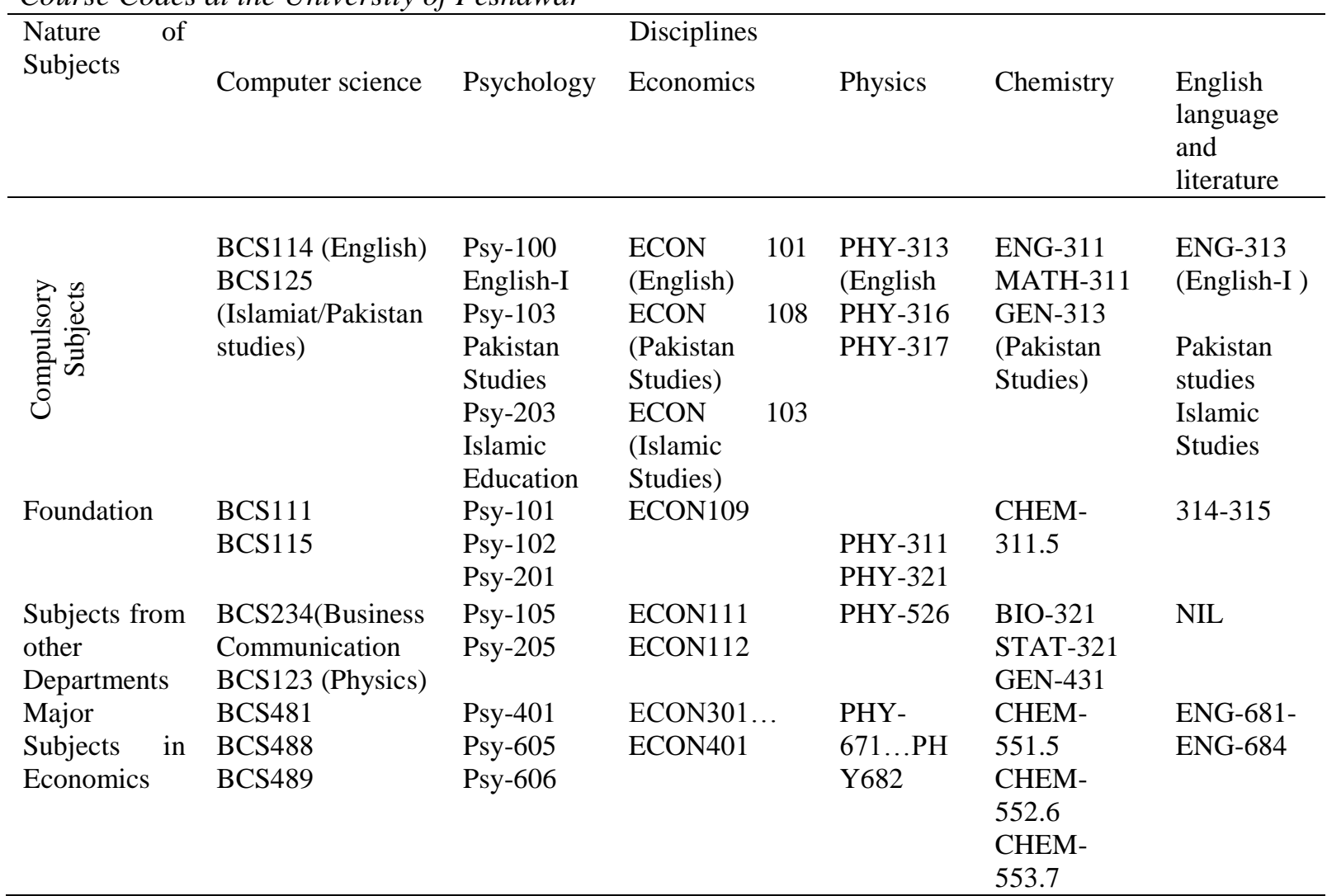

Note: BS Curricula of Computer Science, Psychology, Economics, Physics, Chemistry, English Language and Literature, University of Peshawar

Table 3 shows that University of Peshawar does not have uniformity in codes within the university. It is clear that the university has given different codes to compulsory subjects in different disciplines. Some disciplines started coding from 301 and others from 100. These are undergraduate courses and they are supposed to teach the same compulsory subjects but it is not clear from the codes that they teach the same courses in different disciplines. This would definitely lead to more work and low quality. Moreover, there seems no uniformity in the coding system of foundation, subjects from other disciplines and major courses. The coding system has crossed the figure 500 and even 600 . The 
university has given course codes which even do not follow HEC codes. It is pertinent to mention that courses of 600 level are usually offered at MPhil and PhD levels.

Table 4

Comparison of codes of one Public Sector University (University of Malakand)

\begin{tabular}{|c|c|c|c|c|c|c|}
\hline \multirow[t]{2}{*}{ Nature of Subjects } & \multicolumn{6}{|c|}{ Disciplines } \\
\hline & $\begin{array}{l}\text { Political } \\
\text { Science }\end{array}$ & Archaeology & Zoology & Physics & Mathematics & Economics \\
\hline 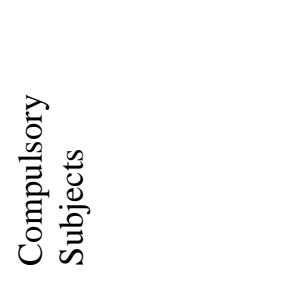 & $\begin{array}{l}\text { ENG-111, } \\
\text { MAT-113 } \\
\text { PST-116, } \\
\text { ISL- } \\
122, \text { CS- } \\
232\end{array}$ & $\begin{array}{l}\text { ENG - } 111 \\
\text { ISL- } 112 \\
\text { MATH- } 113 \\
\text { PS- } 122\end{array}$ & 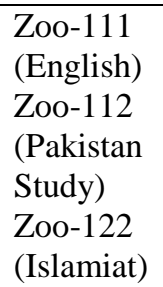 & $\begin{array}{l}\text { Codes of other } \\
\text { department }\end{array}$ & MCC-201, MCC & $\begin{array}{l}\text { ECON101 } \\
\text { (English) } \\
\text { ECON 103 } \\
\text { (Islamiat) } \\
\text { ECON106 } \\
\text { (Pakistan } \\
\text { Study) }\end{array}$ \\
\hline $\begin{array}{l}\text { B. Subjects form } \\
\text { other Departments }\end{array}$ & $\begin{array}{l}\text { ECO-114 } \\
\text {,SOC-115 }\end{array}$ & $\begin{array}{l}\text { STAT-123 } \\
\text { JMC-124 } \\
\text { GEO-125 }\end{array}$ & Zoo-124 & $\begin{array}{l}\text { Codes of other } \\
\text { department }\end{array}$ & $\begin{array}{l}\text { MGC227 MGC- } \\
228,\end{array}$ & $\begin{array}{l}\text { ECON102- } \\
107 \ldots\end{array}$ \\
\hline $\begin{array}{l}\text { C. Foundation } \\
\text { Courses }\end{array}$ & POL-123 & $\begin{array}{l}\text { ARC- } 115 \\
\text { ARC-116 }\end{array}$ & $\begin{array}{l}\text { Zoo-125, } \\
\text { Zoo-241- } \\
245\end{array}$ & $\begin{array}{l}\text { Codes of other } \\
\text { department }\end{array}$ & MFC-243 & ECON xxx \\
\hline $\begin{array}{l}\text { Major } \\
\text { Courses/electives }\end{array}$ & $\begin{array}{l}\text { POL- } \\
351, \text { POL- } \\
471, \text { POL- } \\
481\end{array}$ & $\begin{array}{l}\text { ARC- } 353 \\
\text { ARC-354, } \\
\text { ARC- } 471 \\
73\end{array}$ & $\begin{array}{l}\text { Zoo-353, } \\
\text { Zoo-471 }\end{array}$ & $\begin{array}{l}\text { Phy334---- } \\
\text { phy495 Phy500 } \\
\text { to Research } \\
\text { project }\end{array}$ & $\begin{array}{l}\text { MCC 269--- } \\
\text { MCC272/ MME } \\
271-294\end{array}$ & $\begin{array}{l}\text { ECON 401-- } \\
407\end{array}$ \\
\hline
\end{tabular}

Note: BS Curricula of Political Science, Archaeology, Zoology, Physics, Mathematics, Economics, University of Malakand

Table 4 shows the coding system of the University of Malakand, the university also has not followed any uniform system of coding. The compulsory subjects are common for all the disciplines in the university but they have been given different codes. It means that the university does not have a system for compulsory courses. Similarly, no uniformity has been observed in the codes of foundation courses, subjects from other disciplines and core subjects. When we compare the coding system of the 2 universities given in table 3 and 4 there seems no uniformity. It is interesting to mention that both are situated in one province of Pakistan. There are many chances of students' mobility from one university to another. Although HEC allows migration from one university to another but the lack of uniformity in codes and courses, students' mobility become almost impossible.

After comparing the codes in the HEC curricula and 2 universities, the researchers were interested to find out if there is any uniformity in codes amongst the universities both public and private in Pakistan. The researchers took two disciplines, Physics and Economics, for comparing the coding system amongst the universities in the country.

Table 5

Comparison of Codes in the discipline of Economics at Selected Universities

\begin{tabular}{|c|c|c|c|c|c|c|c|}
\hline & & ${ }^{\mathrm{a}} \mathrm{QU}$ & ${ }^{\mathrm{b}}$ NUST & ${ }^{\mathrm{c}}$ LUMS & ${ }^{* d} \mathrm{VU}$ & ${ }^{\mathrm{e}} \mathrm{UOP}$ & ${ }^{\mathrm{f}} \mathrm{UOM}$ \\
\hline \multicolumn{8}{|l|}{ A. } \\
\hline B. & Compulsory & EC $151 \ldots$. & $\mathrm{HU}$ & SS & ENG201 & ECON 101 & ECON101---108 \\
\hline & Subjects & Basic & & & & (English) & year1 \\
\hline & & Math111... & & & & $\begin{array}{l}\text { ECON } 108 \\
\text { (Pakistan }\end{array}$ & $\begin{array}{l}\text { ECON201...210 } \\
\text { year2 }\end{array}$ \\
\hline & & & & & & Studies) & \\
\hline & & & & & & $\begin{array}{l}\text { ECON } 103 \\
\text { (Islamic } \\
\text { Studies) }\end{array}$ & \\
\hline C. & Foundation & EC101_..ЕC212 & ECO101_.... & ECON 111 & ECO 301, & ECON109 & ECON xxx \\
\hline A. & $\begin{array}{l}\text { Subjects from } \\
\text { other } \\
\text { Departments }\end{array}$ & $\begin{array}{l}\text { EC271----- } \\
\text { EC281 }\end{array}$ & $\begin{array}{l}\text { HUxxx } \\
\text { CS for IT and } \\
\text { ECO } 121 \text { for } \\
\text { Math eco }\end{array}$ & $\begin{array}{l}\text { MATH } \\
101\end{array}$ & $\begin{array}{l}\text { ENG403 } \\
\text { MGT602 } \\
\text { ST404 } \\
\text { EDU101 }\end{array}$ & $\begin{array}{l}\text { ECON111 } \\
\text { ECON112 }\end{array}$ & ECON xxx \\
\hline
\end{tabular}




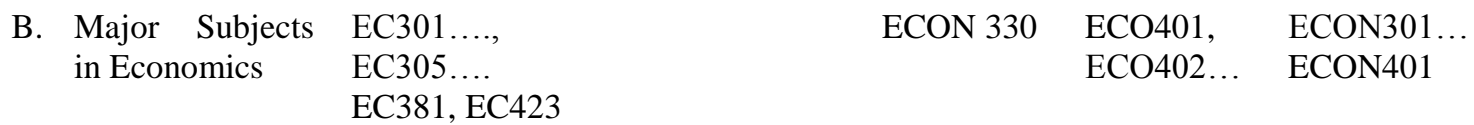

Note: ${ }^{\mathrm{a}}$ BS Curriculum, Economics, ${ }^{\mathrm{b}}$ Quid-e- Azam University, Islamabad, ${ }^{\mathrm{c}}$ BS Curriculum, National University, Islamabad, ${ }^{\mathrm{d}} \mathrm{BS} \quad$ Curriculum, Economics, Lahore University of Management Sciences, ${ }^{\mathrm{d}}$ BS Curriculum, Economics, ${ }^{\mathrm{e}}$ Virtual University of Pakistan, ${ }^{\mathrm{f}}$ BS Curriculum, Economics, University of Malakand.

Table 6

Comparison of Codes in the discipline of Physics at Selected Universities

\begin{tabular}{|c|c|c|c|}
\hline & ${ }^{\mathrm{a}} \mathrm{LUMS}$ & ${ }^{b} \mathrm{UOP}$ & ${ }^{c} \mathrm{UOM}$ \\
\hline Comp & SS100- & PHY -313 & Codes of other departments \\
\hline Subjects & MATH 120 & $\begin{array}{l}\text { PHY-316 } \\
\text { PHY-317 }\end{array}$ & \\
\hline Foundation & Phy100....200 & $\begin{array}{l}\text { PHY-317 } \\
\text { PHY-311 } \\
\text { PHY-321 }\end{array}$ & $\begin{array}{l}\text { Phy111-113Phy121-123, phy231- phy233, } \\
\text { phy241-phy243 }\end{array}$ \\
\hline $\begin{array}{l}\text { Subjects from other } \\
\text { Departments }\end{array}$ & $\begin{array}{l}\text { BIO xxx } \\
\text { CHEM xxx, CS xxx }\end{array}$ & PHY-526 & Codes of other departments \\
\hline $\begin{array}{l}\text { Major Subjects in } \\
\text { Economics }\end{array}$ & Phy $300 \ldots . .$. Phy 400 & $\begin{array}{l}\text { PHY- } \\
671 \ldots \text { PHY682 }\end{array}$ & $\begin{array}{l}\text { Phy334----phy495 Phy500 to Research } \\
\text { project }\end{array}$ \\
\hline
\end{tabular}

Note: ${ }^{a}$ Lahore University of Management Sciences, ${ }^{b}$ BS Physics Curriculum, 2018, University of Peshawar BS Physics Curriculum, 2018, University of Malakand

Table 5 and 6 show the codes given in the subject of Economics and Physics in order to have a comparative analysis of coding in different universities. In Quid-e-Azam, Islamabad (QUI),compulsory courses have also been given the codes of economics, start from ECON 151; National University of Science and Technology (NUST) has used alphabets 'HU' for compulsory and general subjects ; University of Malakand has used 'ECON' general courses start from ECON 271.NUST has used HU for subjects from other departments. QUI has used ECO-300-400 for foundation, core and electives. It is evident that there is discrepancy in the coding system amongst different universities. Table 6 shows that Lahore University of Management Sciences (LUMS) has used SS for compulsory subjects and MATH for Mathematics. Foundation courses start from Phy 100 and move on to PHY200.... Similarly, Phy $300 \ldots$. Phy400. The first digit shows difficulty level of the course. Courses from other departments, like biology or Chemistry, the first 3 alphabets or four have been written before the numerical part of the code.

Table 7

Comparison of codes of one Public Sector University (University of Malakand)

\begin{tabular}{|c|c|c|c|c|c|c|}
\hline & $\begin{array}{l}\text { Political } \\
\text { Science }\end{array}$ & ${ }^{\mathrm{b}}$ Archaeology & ${ }^{\mathrm{c}}$ Zoology & ${ }^{\mathrm{d}}$ Physics & ${ }^{\mathrm{e}}$ Mathematics & ${ }^{\mathrm{f}}$ Economics \\
\hline $\begin{array}{l}\text { Compulsory } \\
\text { Subjects }\end{array}$ & $\begin{array}{l}\text { ENG-111, } \\
\text { MAT-113 } \\
\text { PST-116, } \\
\text { ISL- } \\
\text { 122,CS- } \\
232\end{array}$ & $\begin{array}{l}\text { ENG - 111 } \\
\text { ISL- } 112 \\
\text { MATH- } 113 \\
\text { PS- } 122\end{array}$ & $\begin{array}{l}\text { Zoo-112- } \\
113\end{array}$ & $\begin{array}{l}\text { Codes of } \\
\text { other } \\
\text { department }\end{array}$ & $\begin{array}{l}\text { MCC-201, } \\
\text { MCC }\end{array}$ & $\begin{array}{l}\text { ECON101-- } \\
-108 \text { year1 }\end{array}$ \\
\hline $\begin{array}{l}\text { B. Subjects form } \\
\text { other Departments }\end{array}$ & $\begin{array}{l}\text { ECO-114 } \\
\text {,SOC-115 }\end{array}$ & $\begin{array}{l}\text { STAT-123 } \\
\text { JMC-124 } \\
\text { GEO-125 }\end{array}$ & Zoo-124 & $\begin{array}{l}\text { Codes of } \\
\text { other } \\
\text { department }\end{array}$ & $\begin{array}{l}\text { MGC227 } \\
\text { MGC-228, }\end{array}$ & ECON xxx \\
\hline $\begin{array}{l}\text { Foundation } \\
\text { Courses }\end{array}$ & POL-123 & $\begin{array}{l}\text { ARC- } 115 \\
\text { ARC-116 }\end{array}$ & $\begin{array}{l}\text { Zoo-125, } \\
\text { Zoo-241- } \\
245\end{array}$ & $\begin{array}{l}\text { Codes of } \\
\text { other } \\
\text { department }\end{array}$ & MFC-243 & ECON xxx \\
\hline $\begin{array}{l}\text { Major } \\
\text { Courses/electives }\end{array}$ & $\begin{array}{l}\text { POL- } \\
351, \text { POL- } \\
471, \text { POL- } \\
481\end{array}$ & $\begin{array}{l}\text { ARC- } 353 \\
\text { ARC-354, } \\
\text { ARC- } 471 \\
73\end{array}$ & $\begin{array}{l}\text { Zoo-353, } \\
\text { Zoo-471 }\end{array}$ & $\begin{array}{l}\text { Phy334---- } \\
\text { phy495 } \\
\text { Phy500 to } \\
\text { Research } \\
\text { project }\end{array}$ & $\begin{array}{l}\text { MCC 269--- } \\
\text { MCC272/ } \\
\text { MME 271- } \\
294\end{array}$ & ECON xxx \\
\hline
\end{tabular}

${ }^{a}$ BS Curricula, Political Science, 2018, University of Malakand, ${ }^{b}$ BS Curricula, 
Archaeology, 2018, University of Malakand, ${ }^{\mathrm{c}}$ BS Curricula, Zoology, 2018, University of Malakand, ${ }^{\mathrm{d}}$ BS Curricula, Physics ,2018, University of Malakand, ${ }^{\mathrm{e}}$ BS Curricula, Mathematics ,2018, University of Malakand, ${ }^{\mathrm{f}}$ BS Curricula, Economics, 2018, University of Malakand, Dir Lower

University of Malakand curriculum document did not code compulsory and general courses. Again, the element of uniformity is missing amongst universities keeping in view these 2 disciplines as shown in Table 7.

\section{Conclusions}

1. Curricula for undergraduate studies have been developed under the guidance of HEC in Pakistan, the researchers did not find necessary uniformity in codes of the courses. Some disciplines have given the codes of the discipline concerned to compulsory and even courses from other disciplines/departments. This causes difficulty in understanding of the system and transfer of credits.

2. Some of the disciplines have written full title of the subjects in code which occupies more space in transcription. It is against the normal practices of codes in other universities of the world. It is normal practice that only 2, 3 or 4 prominent alphabets from the title of the course are taken, for instance, 'RS' is written for research.

3. The codes in majority of the cases do not show any sequence to trace the difficulty level of courses. The researchers found that internationally the coding shows difficulty level of a course, the first digit from left shows difficulty but in undergraduate curricula this was missing in many curricula of universities and even in HEC curricula. Normally, undergraduate courses are coded till 499 and 500 is given to research work.

4. Uniformity has not been observed in the alphabetical part of codes. For instance, for Pakistan Studies, some curricula has used 'PS', others have used Pak. Study' and some have used alphabets of the discipline as Mathematics in University of Malakand 'MCC' has been used. Now, a question arises that which course codes will be used in affiliated colleges, academic management system, timetables and transcripts.

5. Almost all universities even do not follow a homogeneous system of coding except a few, for example National University of Sciences and Technology (NUST) follows a unified system. They have given HU to all liberal arts subjects. All other universities have followed coding systems without any logic or understanding. Similarly, Lahore University of Management Sciences (LUMS) have followed a system. They have given SS to all compulsory subjects, and subjects of other departments have been coded as per their codes

\section{Recommendations}

In Pakistan undergraduate curricula is developed under the supervision of HEC to bring quality, uniformity and facilitate sharing expertise. However, the findings reveal that there is no uniformity in the coding system of curricula of different disciplines. There is no uniformity of coding system within a university and amongst universities in Pakistan. Consequently, this confusion leads to wastage of time in academic bodies, low quality in higher education and affects facilitation for students and other stakeholders. Moreover, all the public sector universities have affiliated colleges and they follow their curricula for undergraduate and graduate levels. If the university develop common codes and content for compulsory and subjects from other department as a requirement for general education in undergraduate programs, this would facilitate the universities in assessment and bring uniformity in learning. The universities may have their individual culture but there are problems and issues which are common to all universities. Common codes, common compulsory and general courses will help in facilitating assessment, reviewing the courses and students mobility within provinces and country. If European countries are trying to find solutions to internal and external challenges and facilitating students mobility, to meet the shortage of skills in key areas through Bologna Declaration (Bologna Declaration 1999), why not our universities in one country seek solutions to problems by bringing uniformity.

The following recommendations already implemented are made for bringing uniformity, facilitating mobility of students, avoiding confusion in academic bodies and bringing the curricula at par with the international world.

The overall courses of a degree required maybe divided in 1) General Education requirements taught and 2) Subject specific foundation courses taught in the first two years; 3) subject specific major compulsory courses, and 4) subject specific major elective courses taught in the last two years. 
The general education courses and their codes will be provided by the concerned departments of the university while the others will be framed by the discipline concerned. However, for codes two or three or four capital letters as accepted worldwide for a subject along with three numbers (xxx) will be used to specify each course of the university. The left digit of the three may be used for the hardship level. In other words the courses $1 \mathrm{xx}, 2 \mathrm{xx}, 3 \mathrm{xx}$ and $4 \mathrm{xx}$ will be taught in the first, second, third and fourth year, respectively. It must be kept in mind that the course codes for foundation and general education should be in $1 \mathrm{xx}$ and $2 \mathrm{xx}$, while the major courses in $3 \mathrm{xx}$ and $4 \mathrm{xx}$. Furthermore, some degrees require 5 years like pharmacy and law and hence their codes can be placed in $5 x x$. The research maybe placed at 500 for those programs where the length of the degree is 4 year and 599 for five year degree. The graduate level courses for MPhil/MS/PhD maybe placed into 6xx, 7xx and 8xx, 700 for MPhil research and 900 for $\mathrm{PhD}$ research respectively preceded by the code of the discipline, for instance, EDU 700 for MPhil and EDU900 for PhD in Education respectively.

\section{References}

Brinkley, I. (2008). The knowledge economy: How knowledge is reshaping the economic life of nations. Work Foundation.

Bologna, D. (1999). The European higher education area. The Bologna Declaration of 19 June 1999, Joint Declaration of the European Ministers of Education.

Higher Education Commission, Standardized format / scheme of studies for four-year integrated curricula for bachelor degree in basic, social, natural and applied sciences. Islamabad, Pakistan.

Kromydas, T. (2017). Rethinking higher education and its relationship with social inequalities: past knowledge, present state and future potential. Palgrave Communications, 3(1), 1.

Lahore University of Management Sciences. Course Codes. Retrieved from https://lums.edu.pk/departments

Ministry of Education, National Education Policy 2009, Islamabad.

Ministry of Education, National Education Policy Draft Policy2017, Islamabad.

National University of Sciences and Technology, Islamabad, Pakistan. Course Codes. Retrieved from http://www.nust.edu.pk/Academics/Pages/Undergraduate.aspx

Planning Commission, Pakistan (2016). Pakistan Vision 2025. Retrieved from https://www.pc.gov.pk > uploads > vision2025 > Pakistan-Vision-2025

United Nations (2017).The Sustainable Development Goals Report, New York.

University of Malakand, Department of Physics. BS Physics Curricula. Retrieved from https://uom.edu.pk/departments

University of Malakand, Department of Education. B.Ed. honor Curricula. Retrieved from https://uom.edu.pk/departments

University of Malakand, Department of Botany. BS Zoology Curricula. Retrieved from https://uom.edu.pk/departments

University of Malakand, Department of Political Science. BS Political Science Curricula. Retrieved from https://uom.edu.pk/departments

University of Malakand, Department of Zoology, BS Zoology Curricula. Retrieved from https://uom.edu.pk/departments

University of Malakand, Department of Economics. Retrieved from https://uom.edu.pk/departments

University of Peshawar. Course Codes. Retrieved from https://uop.edu.pk/departments

William, P. J. (2007). Valid knowledge: The economy and the academy. Higher Education, 54(4), 511-523. 